Cinémas

Revue d'études cinématographiques

Journal of Film Studies

\title{
The Sublime Excess of the American Landscape : Dances with Wolves and Sunchaser as Healing Landscapes
}

\section{Maurizia Natali}

Volume 12, numéro 1, automne 2001

Le Paysage au cinéma

URI : https://id.erudit.org/iderudit/024870ar

DOI : https://doi.org/10.7202/024870ar

Aller au sommaire du numéro

Éditeur(s)

Cinémas

ISSN

1181-6945 (imprimé)

1705-6500 (numérique)

Découvrir la revue

Citer cet article

Natali, M. (2001). The Sublime Excess of the American Landscape : Dances with Wolves and Sunchaser as Healing Landscapes. Cinémas, 12(1), 105-125.

https://doi.org/10.7202/024870ar
Résumé de l'article

Dans cet article, l'auteur analyse les paysages des films Dances with Wolves de Kevin Costner ainsi que Sunchaser de Michael Cimino, les considérant comme " théâtres de la mémoire " dans lesquels de nombreux arts sont " re-médiatisés " pour l'écran. Dans le cas qui nous occupe, la relation conflictuelle que les Américains entretiennent avec l'Autre autochtone, en tant qu'obstacle à la doctrine de la Manifest Destiny, est projetée sur les paysages, montée et recomposée en ceux-ci. Dans Dances with Wolves, le nouveau nom du héros suggère la perte de sa subjectivité américaine, ses liens avec les autochtones et une version révisionniste de la Manifest Destiny. Dans Sunchaser, de même, la dynamique Est-Ouest illustre l'espoir de renaissance et de rébellion. Le "sublime pyramidal » de la montagne est le signifiant qui motive le road movie des deux protagonistes. La séquence dans laquelle ils montent à cheval avec les Amérindiens condense les différentes strates de la culture du paysage. Les paysages filmiques font partie des archives contemporaines de la « remédiatisation » : ils instaurent une mémoire conflictuelle et produisent les emblèmes de l'iconologie cinématographique de "l'excès". 


\section{The Sublime Excess of the American Landscape: Dances with Wolves and Sunchaser as Healing Landscapes}

\section{Maurizia Natali}

\section{RÉSUMÉ}

Dans cet article, l'auteur analyse les paysages des films Dances with Wolves de Kevin Costner ainsi que Sunchaser de Michael Cimino, les considérant comme "théâtres de la mémoire" dans lesquels de nombreux arts sont "re-médiatisés" pour l'écran. Dans le cas qui nous occupe, la relation conflictuelle que les Américains entretiennent avec l'Autre autochtone, en tant qu'obstacle à la doctrine de la Manifest Destiny, est projerée sur les paysages, montée et recomposée en ceux-ci. Dans Dances with Wolves, le nouveau nom du héros suggère la perte de sa subjectivité américaine, ses liens avec les autochtones et une version révisionniste de la Manifest Destiny. Dans Sunchaser, de même, la dynamique Est-Ouest illustre l'espoir de renaissance et de rébellion. Le "sublime pyramidal" de la montagne est le signifiant qui motive le road movie des deux protagonistes. La séquence dans laquelle ils montent à cheval avec les Amérindiens condense les différentes strates de la culture du paysage. Les paysages filmiques font partie des archives contemporaines de la "remédiatisation »: ils instaurent une mémoire conflictuelle et produisent les emblèmes de l'iconologie cinématographique de "l'excès". 


\begin{abstract}
The author analyses the landscapes of the films Dances with Wolves by Kevin Costner and Sunchaser by Michael Cimino, considering them as "theatres of memory" in which numerous arts are "remediated" for the screen. Here the conflictual relationship Americans have with the native Other as an "obstacle" to the doctrine of Manifest Destiny is projected onto its landscapes, staged and recomposed on them. In Dances with Wolves, the hero's new name suggests the loss of his American subjectivity, his links with the natives and a revisionist version of Manifest Destiny. In Sunchaser also the east-west dynamic illustrates the hope for rebirth and rebellion. Here the "pyramidal sublime" of the mountain is the signifier that motivates the road movie of the two heroes. The sequence in which they ride on horses together with the natives condenses the landscape culture's various strata. Film landscapes are a part of the contemporary archive of remediations: they instigate a conflictual memory and produce emblems of cinematic iconological "excess."
\end{abstract}

\title{
Introduction: Landscape as "Screen"
}

From many past experiences of one hundred years of moviegoing, spectators silently recognise landscape clichés of which the last one is the resurgent ghost. Always sudden, the images of landscape perpetuate the ecological shock of haunting fragments of Nature returning as interval and pause, background and horizon, a framed Nature which is lost just at the instant of its recording. From a symbolic point of view, since the Renaissance landscapes and cityscapes have opened an outer scene in the narcissistic theatre centred on the human body. In its most traditional definition landscape is a portion of the earth "cut out" from a human point of view, while in rhetorical and philosophical terms, the landscape is a "parergon," as defined by writers as different as Gombrich (1978, p. 107-121) and Derrida (1978, p. 44-94).

The beauty of film landscape is a cryptic spectacle that restages and recycles motifs from multiple sources. Beyond its naturalistic, scientific or documentary rhetoric, landscape imagery has been an archive of memories and fantasies linked to metamorphic ideas of visible nature. As a "deep surface," land- 
scape is an oxymoron of manifest dreams and ideologies, a framed perspective of the known earth functioning as the symbolic frontier of the visible in a society.

With the advent of cinema, the moving landscape, as both emotion and movement, has inherited the archives of landscape painting, theatre decor, panoramas, illustration, photography, and other mises en scène. As in other media, film not only reframes nature, uses and abuses the "unnatural" beauty of its cut-outs, and screens the aesthetic formatting of the profilmic landscape: it also enhances its emotional effects with editing and composition in movement. Restrictively, landscape imagery can be defined as a narrative tool and a stylistic signature for many authors, as a spectacular resource and a polyvalent ornament of well coded genres. In reality, film landscapes are ambivalent backgrounds encoding historical, aesthetic and ideological conflicts in the emblems of narrative representation.

However, in Western culture, even before the invention of cinema, the image of landscape already functioned as a symbolic screen on which notions of nature and national identity, utopias and dystopias, relationships to ancestors and newcomers, and religious and historical narratives had been projected, recomposed and enhanced, presented as dreamed decor or advertised as faithful reproductions. In movies, the landscape, as a window, multiplies ad infinitum the metaphor that has been used to define the cinema itself as a window onto the world. With this imagery, the recorded or staged views of nature not only remediate the special effects of painting (depth, perspective, planes) but also reveal the nature of these special effects of the cinema as a whole, what could be called its technological, emotional, and spectacular dream-work.

On the screen, the spectacle of nature, a decor invisibly encrypted with traces of aesthetic and technological dépenses, maintains the contradictory character of an auratic (re)production offered as a gift, an ornament or a supplement to admire, an attraction to contemplate as a residue of silent cinema resisting mainstream logocentric narrativity (Gunning, 1993).

In all media at all times, from Renaissance painting to lanterna magica, from science fiction to video art, the landscape

The Sublime Excess of the American Landscape: Dances with Wolves and Sunchaser... 
image may be considered a magic interface with the archives of obsolete or recent technologies invested in the spectacle of nature. This spectacle (from picturesque to sublime, from realist to conceptual) also "screens out" ecological and political conflicts, enveloping them under its aesthetic and narrative masks.

The landscapes recreated by the movies have "remediated" and "hypermediated" (to use recent terminology by Jay David Bolter and Richard Grusin [1999] the spectacles of the landscape archive into new moving icons, reconfirming that cinema, as a mechanical eye placed between the human body/eye and the world, is essentially a machine for producing virtual emotions.

The ideal spectator, and film analyst too, should be able to detect and appreciate the never-ending prismatic effects of the landscape dream-work, its brilliant façade of lost conflicts, condensations and displacements. He or she might use film essentially as a mnemonic medium, a Freudian façade of dreams controlled by the illusory perspectives offered by narrative codes, a process of rendering secondary that masks the chaotic likenesses and traumatic associations connected with cinema's pathos formulae. ${ }^{1}$

In the history of American landscape, ideology and ecology, myth and consumerism, and cinema and the graphic arts continuously produce incongruous tapestries of meanings with montages of landscape imagery. ${ }^{2}$ With few exceptions, the link of high art historical icons with popular culture and movies has not frequently been studied by film historian or theorists, as if the aesthetic nature of such excess had frequently appeared as an overly political issue for film criticism. In fact, the ghostly fascination and ecological message of these sources feed Hollywood landscape photographers and special effect experts as well as its audiences' patriotic and touristic reveries, and even explains much of American cinema's worldly commercial empire. However, it is precisely this excess of mesmerising propaganda and technological frenzy that demands an iconological consideration. Often presented as a result of aesthetic choices of the authorial mise en scène (the landscape styles of John Ford, Anthony Mann, Terence Malick or Ridley Scott), this excess of 
sources of the landscape image relates to the particular iconological status of the film as the impure multi-mediator of many archives.

Such excess speaks the language of visual echoes and likenesses from deep cultural strata, even though they may appear neutralised in the narrative economy of the spectacle the audiences pay for. What can be read in the screened spectacle of landscapes, even in the shortened time of a few sequences duly scored by touching music, are the dramatic "theatres of memory" that cinema reactivates, on the stage of which landscape values and conflicts are resurrected and perpetuated.

What follows are analyses of the films by Kevin Costner and Michael Cimino, which show the film landscape as the spectacle of an iconologically layered and deeply conflictual image. This image, caught in motion, recomposed in its elliptical game of narrative backgrounds, and addressed to the viewers as an ideological and poetic advertising, is still capable of producing a dreamy memory effect on them, seducing them while it hides the historical and aesthetic conflicts in the films' recompositions and clichés.

\section{Emblems of Otherness}

In two recent films, Dances with Wolves (Kevin Costner, 1990), and Sunchaser (Michael Cimino, 1996), images of the American landscape are not only the convincing ornament of multicultural conflicts, but they also fill the screen with remediations of the two last centuries of American landscape art. In Costner's historical film Dances with Wolves, the winner of seven Oscars, a wounded soldier of the Civil War, John Dunbar (Kevin Costner himself), refuses to mutilate his leg after an accident and "goes West" with his horse to discover what remains of native culture. His adventure not only reveals to him a new relationship with nature and history, it also introduces to him a new life among the Sioux Indians, where he slowly "goes native." He is fully aware of the destiny awaiting Native Americans, of the final holocaust caused by aggressive politics and the militarist ideology of Manifest Destiny. Thus the film designs the story of Dunbar upon a background of revisionist interpretations of American 
history, the Civil War, ecology and white relationships to natives. Significantly, Dunbar keeps a journal in which he writes and draws from "nature" what he sees.

In Cimino's road movie odyssey Sunchaser, which was barely distributed and discussed in the U.S., a young mixed-blood Navajo named Blue (John Seda), ill with cancer, kidnaps Michael Reynolds (Woody Harrelson), an oncologist, from his Los Angeles hospital and forces him to leave the city and travel to a sacred Navajo mountain and lake in Arizona, the country of his ancestors. A black-and-white print of that landscape found by Blue in an old book is their only guide.

Certainly, with their symbolic movement back to Native American territories, the main characters of these two films abandon a culture of violence and rediscover the cultural and natural landscape of the native "Other." However, in both these films the landscape imagery is not only a "scenic view" ideologically exposed, but also a spectacular ornament of the plot, a coded Hollywood icon uncannily mixing, as always, high clichés from painting with tourist advertising and cheap picturesque illustrations. Such encoding is even subtly exhibited in landscape details. In fact, in both films, small images of landscape (the print in Sunchaser and the pages of the journal in Dances) implicitly condense micro-themes that, later, the film technology will "blow up" to spectacular effect. Both the old print of Blue's book and the pages of Dunbar's journal, with their connotations of obsolete media from print culture, appear both remediated and hyper-realised by (big-)screen culture. In fact, the blackand-white print and the handmade drawings (and writing) open the paradigmatic chain from page to screen that makes the landscapes created by the cinematic perspective symbolically deeper.

Thus, while these little pages become part of the plot, they also represent within the film an interface that reconnects us with the virtual archive of American landscape imagery. They remind us that the landscape that the characters of the two films discover had already been largely "formatted" over two centuries of American drawing, painting, prints, illustration, photography, and movies. Particularly in the Western genre and in road movies, emblematic backgrounds and locales have been recycled 
as nostalgic illustrations of the mythical version of the American history, and as items for both American and world audiences. However, as the art historian Anne Hollander has written in her book Moving Images (1989), Hollywood is not used to revealing its "thefts" from art history. Rather it keeps its own archives well-protected (from the common spectator as well as from the industrial arena) under the seducing mask of the infinitely renewed spectacle of special effects.

Moreover, the itineraries of Costner's and Cimino's characters, with their American "anabasis," redesign symbolically established "lines of escapes" (the term is Gilles Deleuze's) that have often been represented in Western and road movie plots. While experiencing a rejuvenating encounter with their new native partners, these male characters redraw the symbolic directions of Manifest Destiny, literally traversing landscape icons that are still present in the postmodern popular culture with their encrypted advertising technique.

\section{The Subject is the Landscape}

Dances with Wolves is part of a specific revisionist tradition of Westerns that started after World War II and continued through to the opposition to the Vietnam War, with films such as Broken Arrow (Delmer Daves, 1950), Little Big Man (Arthur Penn, 1970), and Blue Soldier (Ralph Nelson, 1970). With the contributions of Native American historians, revisionist films, books, and art exhibits have rebuilt versions of a multicultural and critical history of the West, not without fierce resistance and polemical attacks from conservative historians, art historians and other guardians of American ideology in the agitated seas of museum politics and the "crises of art history."

The title of Costner's film, Dances with Wolves, which is also the title of the novel by Michael Black, ${ }^{4}$ who also wrote the script, plays ambiguously with the word "dances." As the plural of the noun "dance," it evokes a poetic description of people performing a ritual. Dances with Wolves lets us imagine an ethnographic scene in which characters dance, or in which "dances" are performed in the company of wolves. As we later understand, the expression is the translation of the first name 
that the hero is given by the natives, after they have seen him running around his fire and jumping alone like a wolf, and even becoming the friend of a wolf, in the "country of wolves."

Thus the hero who embraces a new life and renounces his English onomastics symbolically leaves behind his old "subjectivity" and acquires a new one. In this way, the title Dances with Wolves is revealed to be the description of a virtual landscape (a painting, a ballet, a film sequence, etc.) that may be quoted or staged by the film itself later. The new name of John Dunbar does not come from a patriarchal Christian culture based on the Name of the Father, but from a native culture based on a different ecology and relationship with (Mother) Nature.

Moreover, "dances" is also the verbal form of an omitted third person, the virtual English subject he/she, that has become an invisible, ghostly and unnecessary subject(ivity) of the action, an invisible subject substituted by the entire expression "dances with wolves": a true ecological name, a landscape-name. The "white man and English subject," John Dunbar, by leaving his original country, also becomes a "blank" subject. He loses the condition and the name of an English speaking "subject" and is reborn as the Native American Dances with Wolves. His new name, the gift of the Indians renaming him in a ritual, results from the point of view and the collective "gaze" with which Native Americans reframe Dunbar in his solitary but peaceful approach to the wilderness, an encounter that becomes his new individualising subjectivity.

Here the western landscape, frequently represented in paintings and photography from the point of view of the white conqueror surveying it (Boime, 1991) is the place where a white man is benevolently observed and welcomed by Native Americans, where he is renamed and absorbed by their culture. In this revisionist spirit, the name "Dances with Wolves" both describes and symbolises the fusion of the hero with his new cultural environment. In fact, in a third sense, the words "dances with wolves" suggest also "(he) dances like the wolves," that is, a metaphorical devenir animal (Deleuze) of the one who performs the dances. Dunbar's "becoming animal" is part of his "becoming landscape" as well. 
Dunbar's renunciation of his English "Subjectivity" stresses his new and friendly relationship with nature. He becomes nature without grammatical existence, a new human "dances with wolves," where the ambiguity of the signifier "dances" depicts the filmic "dissolve" of two cultures in the same name, the cipher of the Subject in the new landscape language.

After the title, in a classic narrative display, the full sense of the new name will be produced by the events and displacements of the plot, and given first to the hero himself, and then to us, the audience, as an emblematic retroactive gift. However, even though the title functions in a classic way as a paratext, an encoded anticipation of the story, it also works, after the fact, as an ambivalent parergon, as a landscape both outside and inside the story, an eccentric inscription of Dunbar's name on which the film's meaning depends. Significantly, this symbolical dance takes place in a solitary landscape where apparitions of humans and animals are as sudden and uncanny as the spatial and temporal dimension of dreams. From another point of view, the woman Dunbar meets in the tribe (Mary McDonnell) is also central to the story. She has also been adopted by the natives as a child after the killing of her family by the Pawnee tribes, and emblematically renamed "Stands with a Fist." She has almost forgotten her first language, English, and she will remember it as a retrieved language only with the help of Dunbar, while she translates and mediates between him and her new people. For the whites, she has become the impure Other absorbed by native culture. Here, miscegenation among white and red cultures, at the centre of many Westerns such as The Searchers by John Ford, represents the symbol of a peaceful healing from wounds produced by the violence of both whites and natives. For Dunbar, Stands with a Fist, reborn under her suggestive name, is the perfect match, and also a model because she has already accomplished the transformation of her own identity into that of the Other. Although Dunbar knows that the whites are coming, nevertheless he wants to become part of this disappearing Otherness.

However, even if his move to the West was meant to be revisionist and progressive, Costner has been criticised for having

The Sublime Excess of the American Landscape: Dances with Wolves and Sunchaser... 
centred the narrative on a white couple (Walker's, 1996). Actually, we can observe that the two main characters become outcasts obliged to face the violence of their original culture while they approach the culture of the Other. In fact, for the white soldiers, Dances with Wolves becomes a traitor to his race, language, and culture, the lost Subject who has renounced English culture, name, and territory. As the film closes, Dunbar is chased for being an army deserter by the white soldiers and disappears into a snowy forest of the mountains. No reconciliation will be possible between "Dances with Wolves," "Stand with a Fist," and them. And no real "run for cover" into nature seems possible for those who have become the uncanny Other of white culture. Even if the end of the story seems open as the couple disappears on the horse, the new "fold" of the landscape cannot warrant a happy escape or even a nomadic life.

From the point of view of the directions symbolically inscribed in the American iconography of voyage and exploration of the new frontier in literature and films, tired heroes (we could also call them symbolically tired subjects) always go West, seeking regeneration and rebirth. From this topological point of view, "going West" may also signify "going crazy," when the choice of freedom is an escape from rationality, public life, family traditions and social rules (Pétillon, 1979). Yet, "going West" also means "returning to the past," rediscovering the primeval landscape of American history and what remains of the "innocent" wilderness of native cultures. In many paintings of the nineteenth century, where the point of view of the artist implicitly prescribes that of the spectator, the left or "west" side of the canvas is frequently occupied by the primeval forest, with a few Indians, symbols of primitive America's past, its savagery and pre-history. On the right or "east" side, and frequently depicted as part of the far horizon and miniaturised in "long shots," we find domestic animals, villages, pastures, trains and industrial chimneys: the realities of the contemporary white progress and its Manifest Destiny. Examples of this orientation of the canvas may be found in works by Thomas Cole, Albert Bierstadt, Emanuel Leutz, and Tomas P. Otter (Aikin, 2000; Faling, 2000). For example, in "Progress," the title of a painting 
by Asher B. Durand (Maddox, 1988), progress occupies the right side and advances from right to left, from east to west, with north in front of the viewer. In this and other similar paintings, which are already cinematic mises en scène of the landscape, the vision of Manifest Destiny is represented by a hazy or clear but always luminous horizon at the right of the composition.

Thus it is that Dunbar goes West, in the direction of the "left" past, where he will find a different future and a new multicultural identity. Regression and escape from the advancing white civilisation here is recoded as a progressive and "revisionist" direction that melancholically traces the moral odyssey of a nonviolent hero. The topology of the nineteenth century is revisited and politically corrected.

In this film Native Americans' more "natural" relationship to nature, still the subject of historical debate, becomes the background of Dunbar's transformation, his new natural society. The film shows plains and hills, villages and rivers, where idealised natives and animals live freely as "natural" inhabitants.

At the beginning of his adventure Dunbar lives in a small abandoned fort, constantly writing in his journal and sleeping alone in his "hermitage," which stands at the very heart of the landscape. This iconography of the isolated hero also uncannily perpetuates those Renaissance paintings in which Saint Jerome lives alone in a grotto with his books and a lion. Dunbar, too, chooses his landscape of solitude and meditation, while the lion is substituted by a wolf. This landscape, from which the natives, the wolf, the buffalos and also the menacing Pawnee Indians and the white soldiers all suddenly surge, recuperates the iconography previous to the ideology of Manifest Destiny, as it was diffused during the first half of the nineteenth century. Similar to those naive "Peaceable Kingdoms" painted by Edward Hicks in the 1830 's in which the foreground, an Eden of domestic and wild animals, is presented against a background of pilgrims and natives peacefully meeting, Costner's landscapes recall a different period in the contact among white and native peoples, one which sketched another impossible history in a utopian manner. Pictorially, the camera and the photography by Dean Semler

The Sublime Excess of the American Landscape: Dances with Wolves and Sunchaser... 
focus on the solitude of South Dakota and on panoramic views of the Badlands, while the soundtrack by John Barry underlines the recomposition of the harmony of nature and culture. No high mountain or peak, no overwhelming canyon is framed by the camera. Rather than using the flamboyant, sublime style of the huge canvases by Albert Bierstadt, Frederick Church or Thomas Moran, who encode them with a luxuriant imperialistic rhetoric and anticipate the wide-screen format of Hollywood landscapes, Costner's film evokes and imitates the modest size of the paintings by George Catlin, Karl Bodmer and Charles Bird King, their fresh illustrations of Natives with those little buffalos, picturesque backgrounds or coloured portraits of Indian chiefs. Icons of naive glamour, at the beginning of the nineteenth century, they still suggest an attractive and innocent difference, that of the natives' integration into Nature.

In the film, even the Indians hunting buffalo are presented as obeying an ecological necessity, in that few animals are actually killed. Yet historical reality tells us about the buffalo extermination initiated by the whites and in which even painters, such as Bierstadt, participated, as the Australian art historian Robert Hughes writes in his book American Visions (1997).

In the film, these landscapes are also the last pictures the hero will keep in his memory before the arrival of the white conquerors. However, Costner's ecological vision has the melancholy tone of an elegy that, somehow, blurs the violence of those tragic and savage conflicts. As several generations of nineteenth-century iconographers of the American wilderness, from Thomas Cole to Frederick Church, from Albert Bierstadt to Emanuel Leutz, from Frederic Remington to Charles Russell (these latter two were the first authors of scenes with cowboys, horses and natives [Hughes, 1997]), already knew, their successful and expensive canvas of natives in untamed landscapes were the manifestos that implicitly anticipated the tragic results of final massacres and ecological disasters.

\section{Pyramidal Sublime, Healing Nature}

Sunchaser, by Michael Cimino, presented at the Cannes Film Festival in 1996, was not widely distributed in the United 
States. Perhaps the reasons for such a silent censure are to be found in the ambitious agenda of the film, confirming both Cimino's originality and his misadventures (cf. Heaven's Gate) with distributors and producers. The story starts in Los Angeles, where Blue (John Sada), a young gang murderer and mixedblood Navajo dying of cancer, is assigned to doctor Michael Reynolds (Woody Harrelson). (The filmmaker worked with young gang members in Los Angeles and with Navajo Indians to make the character of Blue believable [Cimino, 1996].) Blue kidnaps Michael and, using a gun, forces him on the road to Arizona, to Last Canyon Creek at the heart of the sacred Navajo territories, where he hopes to find the old Medicine Man, Sunchaser, who can heal his cancer. In the film the landscape, at times uncannily echoing the reddish canyons of the painter Thomas Moran, is a utopian scene where ancient cultures and new ones share a healing relationship with nature.

When he was still in prison, Blue found an illustration on the first page of a nineteenth-century book of travel, presumably written by a Native American. The black-and-white print depicts a high mountain and a lake with which, for few seconds, Cimino's camera fills the screen, while Blue repeats a mystical formula: "Beauty is into me, Beauty is around me, Beauty is above me..." Such a refrain anticipates his ecstatic immersion into the landscape.

This small image, a blueprint of the real landscape, which is delayed until the end of the film, plays the role of both an intratextual and extra-textual iconological origin, the visual key or the micro-theme of the "sacred mountain" later presented in full colour by Cimino, for a few instants, in all its sublime majesty as a healing frontier. On the screen, this view technically results from the fusion of different shots from different places. Even in this trick, Cimino imitates painters such as Church, Bierstadt, or Moran, who in their elaborate canvases painted in studio recomposed views using their multiple sketches from nature, reworking them for enhanced mises en scène. Similar to the coloured peaks of these nineteenth century avatars, Cimino's high mountain inscribes itself among those towering architectures of nature that we might call pyramidal sublime. The 
canvases of Claude Lorrain, Turner and John Martin, often diffused as prints on both sides of the Atlantic, had for decades perpetuated their radiant light and halos of a religious mood, their landscapes as architectural constructions, their awe-inspiring atmospheres of doomsday's special effects. Moreover, in the Romantic era and beyond, the spectators had even seen them as uncanny imitations, made by nature itself, of the wondrous architectures of a much more distant country, Egypt, with its sublime pyramids and sphinxes. In fact, during the nineteenth century and later, several vogues of Egyptomania fervour produced examples of Egyptian-style cemeteries, buildings for civil use, and finally movie-theatres (Carrott, 1978; and Lant, 1992). And Egyptian terms were used to name natural monuments in wild territories that had been reproduced during photographic explorations. Moreover, religious revisions of biblical and masonic myths suggested the belief that God had disseminated "Egyptomorph" landscapes, pyramidal mountains, and rocky sphinxes as biblical decor and symbols of American Manifest Destiny (Danly, 1988; and Vidor, 1996).

With its religious connotation, Sunchaser, the name of the mythical medicine man, represents also a condensation of the dual Subject of the film, the Janus-like male couple of Blue and Michael seeking a new "sun." In fact, as we see through a recurrent dream of Michael's, Blue, who has become bald because of his cancer, has a striking resemblance to Michael's older brother who had also died from cancer when he was a boy. Michael himself had been asked by his brother to discontinue treatment and to let him die. In the end, the sacred Navajo landscape represents the healing scene for both Blue and Michael, for their spiritual anxiety and physical sickness. For Blue, the mountain and the lake are the final scene of the mystical reunion with his ancestors. For Michael, it becomes the psychoanalytical scene where he reformulates his vocation for medicine through the help he gives Blue. After all their adventures, reciprocal challenges and encounters with other people, while they climb the sunny peak of the mountain, Michael gives Blue his brother's ring and leaves him to the Medicine Man, ready to return to his own life, presumably a renewed man and doctor. 
Significantly, the final scene is filmed from the non-human point of view, that of an eagle overlooking the action. With a cinematic dissolve, we see Blue literally disappearing into the nearby lake, mystically reunited with the landscape of his Ancestors. This magic dissolve puts an end to the debates between the two heroes about ancient and contemporary medicine and their relationship to nature. With this final touch, Cimino's film exhibits more than a hint of "new age" ideology about the recuperation of a multicultural and healing Nature. Far from the boiling streets of Los Angeles, the country of the sacred sublime, once subdued by the white race, keeps its magic healing power. The landscape, linked to the beliefs of the natives, becomes the new vernacular screen upon which a contemporary road movie projects its confused romanticism tinted by multicultural conflicts. ${ }^{6}$ The iconological compromise among contrasting cultures, cults and medicines is given a cinematic solution with a dissolve which, almost in dream-like terms, produces a condensation and displacement of Blue's body in the landscape, a visual dissolution of the plot that does not give any other explanation of the ghostly disappearance of Blue into the thin, luminous air.

There is a sequence in Sunchaser which suggests the layered meanings involved in the moving images of landscape, what I call the iconological excess of Hollywood landscape imageries. Almost at the end of their trip, Blue and Michael, while approaching the mountain and the lake by car, suddenly meet a group of Native Americans running on wild horses. With the rapid movements of the camera combined with an epic, sentimental score, this sequence is visually attuned with the exalted psychic state of the characters approaching the sacred territory. This relationship between sound and image stresses their dreamy, visionary movement in a time and space that is greater than that of the story. Cimino stages the natives, who ride as Indians did in Western films, together with the two contemporary heroes from the road movie, thus creating a carnivalesque, joyous sequence, unique in the entire film, which is also an example of his emphatic grand style.

From an iconological point of view, the excess of this sequence shows something beyond its audiovisual spectacle. In 
the sudden ride of the Indians on their horses and the car, we recognise multiple iconographic strata and echoes from painting, photography, ballet, and cinema. How can we define this excess of mnemonic emotions and spectacular motion that only movies, the century-old art of fragments and shocks, of suspense and surprise, of montage and drift, are still capable of creating on the large surface of the screen?

Such an effect of mnemonic density can be produced mainly by the sheer "kinematics" of landscape and characters in movement on a screen. We can thus call this rapid, shocking effect on the minds of spectators a putting cinema's excess as an archival art on screen. The image of landscape in film may be the ideal model of this effect. In fact, as an ornament with natural appeal, the edited landscape of cinema, among those of other media, is the only one that is able to surge, as a fragmented memory, in a time dimension that is never completely erased by the narrative rules.

In Sunchaser, this excess of the moving landscape certainly functions as an ideological screen wherein the dionysian fantasia of "riding together in the landscape" conceals the contradictions of races (white and native), technology (horses and cars) and film genres (Westerns and road movies, built by different ideologies). For a few minutes, historical or cultural conflicts appear resolved in the visual feast staged on the bright background of nature. As in a "carousel" or in a circus, in which horses and other vehicles run with people in the same circuit, here several iconographic traditions are re-composed by the filmic, and cinematic, rhythm. For a moment, painful contradictions find a carnivalesque solution in a moving composition. Also, as in the semi-pagan religious processions and "feasts of gods" staged by painters of the Renaissance (Titian, Bellini, and Mantegna), here white, native and mixed-blood people dance together in an oneiric "compromise." Or rather, the landscape with horses and car features here a conflictual return of the pagan natives whom Christian people have fought and conquered. Moreover, the scene takes place in Monument Valley. Thus, we can say that in this sequence white and native simultaneously and symbolically run in three different spaces: as actors, in the 
space of the real Arizona landscape, with its historical scars and pyramidal architectures; as symbolic figures, in the universe of American landscape painting, with its multicultural connotations and ideological recompositions; and, finally, as film characters they run across the archival screen of American cinema, metonymically represented by Monument Valley, the most "tired" cliché of Western iconographies.

The Western genre, that "mannerist" universe that came out of Manifest Destiny ideology, anachronistically meets the road movie icons which have taken its place (Assayas, 1982; and Morsiani, 1994). As in an ecstatic reconciliatory movement, film composition, music and colour produce a symbolic climax. For few seconds, the excess of screen memory aesthetically recomposes contradictions in the landscape.

In a similar way the end of the film, staged as the hyper-realisation of the pyramidal sublime, gives high art ghosts of past landscapes a new role in the reconciliation that substitutes for the rhetoric of Manifest Destiny. As if God had given these sublime beauties to the white race as a fatal gift, the enchantment of landscape is reactivated by confused "new age" beliefs in a different way to heal sickness. In fact, the critical encounter of Blue, as patient, and Michael, as doctor, puts contemporary medicine on trial. And in the background, as in the mythical structure of a fairytale, female characters help the main heroes. Michael's wife from Los Angeles; Dr Renata Bernbauer (Anne Bancroft), the new age "witch," who gives Michael and Blue a ride; and the Native American grand-daughter of the Sunchaser: all have a protective role to play with the male heroes who, themselves, are engaged in their conflictual relationship. As a final touch, these secondary female allies echo contemporary feminist ideas about the religious return to Nature as motherly Goddess, in the panorama of ecological millenarianism.

\section{Conclusion}

The filmic landscape, like any landscape image, is encrypted with the mnemonic excess of historical and ecological conflicts. In the future global archive, film landscapes will still fill our screens, just as the reproductions used by Aby Warburg filled his 
Mnemosyne boards, mapping the resurgence of Western and Eastern conflictual iconographies as well their destiny of images without aura (Manovich, 2000). However, no ordered archive, including all the arts of landscape, with all its paradigmatic files interactively available, will exhaust what I call the iconological excess of the cinematic landscape, because only the landscapes of cinema retain their fascinating contradictions and mnemonic effects derived from the truly crystalline nature of the screen (Deleuze, 1985).

The cinema, the "old" photographic cinema as "symbolic form," has the privilege of a flickering indexical memory, even when it is digitally remorphed, imitated or remediated by other arts and other media. In a time of the accumulation of databases, the cinema, which is just one region of the kaleidoscopic geography now in formation, still could be considered the archaeo-logic of any image-movement. Cinema still condenses the richest "theatres of memory," as Frances Yates (1966) calls them; is still the most effective apparatus for attention and distraction, as Jonathan Crary (1999) or Walter Benjamin (1978) might phrase it; and, finally, is the most powerful puissances $d u$ faux, as Deleuze (1985) has written. I call all these mnemonic powers the iconological powers of cinema, and the very object of a screen iconology. ${ }^{7}$

My analysis of these two films stresses the echoes of some past icons in their representation of the American landscape, which in itself has always constituted a powerful mnemonic theatre, staging contradictory values with oneiric, hyper-realistic spectacles. Decor and backgrounds have been a subtle and powerful "instrument" of American identity, constantly played by Hollywood ideology as a visual score to its popular narratives. Landscape has been the advertising rhetoric of both the utopian and the imperialistic side of American ideology. It has kept alive the dystopias of its history and the vernacular dreams of its people, who have also projected them in movies. Such a resurfacing iceberg ${ }^{8}$ that we still face today in contemporary American cinema is the emblem of a civilisation that has based so much of its empire throughout the world on the rescreening of its own landscape ghosts from the past, launched into an imaginary future. 
After the false ends of art, cinema, and perhaps landscape art, is landscape imagery still a pleasurable spectacle? Or, rather, does it betray ecological slow catastrophes taking place in front of the camera at 24 frames per second? Are film landscapes, so perfected by special effects, the final archiving of nature in a rhizomatic cinémathèque of lost pathetic formulae? Is the screen our glass bell protecting us from some sublime and terrible truth?

I believe that we cannot answer these questions proposed by film culture with a limited notion of what is the analysis of film-of American cinema or of other cinemas, for that matter. The sublime ambiguity of Hollywood (and other landscapes) cannot be exhausted by a narratological or cognitivist approach because it is a tapestry of art historical subtexts and historical conflicts, enhanced by filmic condensations and displacements, as they take place on the flickering temporality of the screen. Instead, a multi-mediatic, hypertextual, iconological analysis of film is truly contemporary with the very persistence of the screen as a symbolic form of our excessive memory.

\section{Rhode Island School of Design Rhode Island College}

\section{NOTES}

1. For the term pathos formulae, my reference of course is to Aby Warburg, translated into film theoretical terms for example in Natali (1996). On Warburg's iconology see note 7 below. Digital technology is now advertising as brand new its ideology of the accumulation of data, remediation, bypermediation and interactivity. For these terms see Bolter and Grusin (1999). The authors describe the interactions among media and the ideological remorphing of previous visual rhetoric in new graphic and interactive strategies. For a definition of cinema's archaeology and its role as an interface, see Lev Manovich, The Language of New Media, Cambridge, MIT Press, forthcoming.

2. As example of this is the famous series of "Marlboro Country" landscapes advertising cigarettes in contemporary magazines such as Time and Newsweek, with full pages of mountains, cowboys, and horses captured in warm sunlight or bluish shadows, with pictorialist suggestions coming from sensual details or mystic scenic views. Together with vernacular calendars, tourist booklets, train schedules, and luxury car publicity, all of these perpetuate the imagery of a dreamy epic "everyday life" of American people, targeting both local and global visual culture and perpetuating, from the history of painting and photography, atmospheric compositions that are centuries old.

3. See the article by Alain Trachtenberg (1991) about the controversial exhibit "The West as America" at the National Museum of American Art in Washington D.C.

4. The author has also written Marching to Walhalla: A Novel of Custer's Last Days, 1996.

The Sublime Excess of the American Landscape: Dances with Wolves and Sunchaser... 
5. In the case of F. Church, he exhibited in New York his huge "Heart of the Andes" with exotic plants, curtains, dimmed lights and rows of chairs for the spectators who paid a ticket to contemplate the hyperreal luminosity and the infinite details of his pre-cinematic panorama, a dissolve of various views of the Andes. See Robert Hughes (1997, p. 161-62).

6. In Thelma and Louise, by Ridley Scott, feminist issues are superbly enhanced by the mythical background of Arizona's reddish views. The two heroines, mystically united in suicide, are "frozen" by Ridley Scott in the final tableau which suspends them in the air over the canyon, as in a painting by Mark Tansey.

7. The term "iconology" comes from European "ermetic" culture, Renaissance art history and history of the art history. Recently, in the U.S., it has been recoded in terms of cultural studies, new art history, and American art history. I would like to stress that the term iconology, in its most hybrid and conflictual version, puts the accent on exchanges of cultural figures and multi-media technologies deposited in artifacts. As such, this version was already practised by Aby Warburg himself, who in fact has recently been "rediscovered" by art historians and visual culture researchers as the father of visual culture approaches. As is well known, Aby Warburg perceived the Renaissance as a deeply heterogeneous visual culture in which the most innovative protagonists were attracted by the rediscovered icons of the ancient pagan world, in an age of progress, religious changes, new science and explorations. The idea of conflictual representations in Renaissance art, animated by pathetic formulae, is the original contribution of Warburg. At the end of his life, in 1925-28, he confronted ancient iconographies and modern images "without aura" through montage, on the panels of his last Mnemosyne project. This project, now frequently quoted in visual culture studies, has affinities with the dialectical use of contradictory and pathetic images, bodies, and landscapes in the editing rhetoric of the cinema. The bibliography on Warburg and iconology is vast. See as recent examples the articles by Kurt W. Forster (1996) and Hal Foster (1996), and the book by Philip A. Michaud (1998). For the term "iconology" as used in recent reformulations of American art history, and for landscape culture, see the works by art historians Leo Marx, David Miller, David Lubin, Angela Miller, William Truettner, Albert Boime, and Simon Shama.

8. I write these lines on "iceberg" conscious of its psychoanalytically inflated overtones and having seen the successful iceberg effects in the film Titanic. I believe that by not giving due consideration to iconological "icebergs" film historians and critics risk running aground. Economically, Hollywood's icebergs, as other landscapes, have been part of its empire, and are certainly another example of "pyramidal sublime."

\section{BIBLIOGRAPHICAL REFERENCES}

Aikin, 2000: Roger Cushing Aikin, "Painting of Manifest Destiny: Mapping the Nation," American Art, Fall 2000.

Assayas, 1982: Olivier Assayas, «La Ligne de fuite perdue. Notes sur l'espace américain", Cahiers du cinéma, no. 337, 1982.

Benjamin, 1978: Walter Benjamin, "The Work of Art in the Age of Mechanical Reproduction," in Hannah Arendr (ed.), Illuminations, New York, Schocken Books, 1978.

Boime, 1991: Albert Boime, The Magisterial Gaze: Manifest Destiny and American Landscape Painting c. 1830-1865, Washington, Smithsonian Institution, 1991.

Bolter and Grusin, 1999: Jay David Bolter and Richard Grusin, Remediation: Understanding New Media, Cambridge, MIT Press, 1999. 
Carrott, 1978: Richard G. Carrott, The Egyptian Revival: Its Sources, Monuments, and Meanings, 1808-1858, Berkeley, University of California Press, 1978.

Cimino, 1996: Michael Cimino, "Michel Cimino Interviewed by Serge Toubiana," Cahiers du cinéma, June 1996.

Crary, 1999: Jonathan Crary, Suspensions of Perception: Attention, Spectacle, and Modern Culture, Carnbridge, MIT Press, 1999.

Danly, 1988: Susan Danly, "Andrew Joseph Russell's The Great West Illustrated," in Susan Danly and Leo Marx (eds.), The Railroad in American Art: Representations of Technological Change, Cambridge, MIT Press, 1988.

Deleuze, 1985: Gilles Deleuze, L'Image-temps, Paris, Minuit, 1985.

Derrida, 1978: Jacques Derrida, "Le parergon," La vérité en peinture, Paris, Flammarion, 1978, p. 44-94.

Failing, 2000: Patricia Failing, "Getting the Big Picture," ARTNews, May 2000.

Forster, 1996: Kurt W. Forster, "Aby Warburg: His Study of Ritual and Art on Two Continents," in October, no. 77, Summer 1996.

Foster, 1996: Hal Foster, "The Archive Without Museum," in October, no. 77, Summer 1996.

Gombrich, 1978: Ernst Gombrich, "The Renaissance Theory of Art and the Rise of Landscape," Norm and Form: Studies in the Art of Renaissance, London, Phaidon, [1966] 1978, p. 107-121.

Gunning, 1993: Tom Gunning, "Now You See It, Now You Don't: The Temporality of the Cinema of Atractions," The Velvet Light Trap, Fall 1993.

Hollander, 1989: Ann Hollander, Moving Pictures, New York, Alfred A. Knopf, 1989.

Hughes, 1997: Robert Hughes, American Visions: The Epic History of Art in America, New York, Alfred A. Knopf, 1997.

Lant, 1992: Antonia Lant, "The Curse of the Pharaoh, or How Cinema Contracted Egyptomania," October, no. 59, 1992.

Maddox, 1988: Kenneth W. Maddox, “Asher B. Durand's 'Progress' (1953): The Advance of Civilisation and the Vanishing American," in Susan Danly and Leo Marx (eds.), The Railroad in American Art: Representations of Technological Change, Cambridge, MIT Press, 1988.

Manovich, 2000: Lev Manovich, "Database as a Symbolic Form," Millennium Film Journal, Spring 2000.

Michaud, 1998: Philip A. Michaud, Aby Warburg et l'image en mouvement, Paris, Macula, 1998.

Morsiani, 1994: Alberto Morsiani, «La Perdita del centro. I Crocevia del road movie e le terre di nessunom, in Scene Americane, Parma, Pratiche Editrice, 1994.

Natali, 1996: Maurizia Natali, L'Image-paysage. Iconologie et cinéma, Paris, Presses Universitaires de Virıcennes, 1996.

Pétillon, 1979: Pierre-Yves Pétillon, La Grand Route. Espace et écriture en Amérique, Paris, Seuil, 1979.

Trachtenberg, 1991: Alain Trachtenberg, "Contesting the West," Art in America, September 1991.

Vidor, 1946: King Vidor, "La Sphinge indienne», in Natali (1996).

Walker's, 1996: Michael Walker's, "Analysis of the Film Dances with Wolves," in Ian Cameron and Douglas Pye (eds.), The Book of Westerns, New York, Continuum, 1996.

Yates, 1966: Frances A. Yates, The Art of Memory, London, Routledge and Kegan Paul, 1966.

The Sublime Excess of the American Landscape: Dances with Wolves and Sunchaser... 